\title{
A REFLEXEK, TANULÁS ÉS VISELKEDÉS - BETEKINTÉS A GYERMEKI ELMÉBE CÍMÜ KÖNYV (RECENZIÓ)
}

\author{
Szerző: \\ Hajdú Péter \\ Debreceni Egyetem
}

Szerző e-mail címe:

peterhajdup@gmail.com

\section{Lektorok:}

Szilágyi Barnabás

Debreceni Egyetem

Mező Katalin

Debreceni Egyetem

Schréder Veronika

Debreceni Egyetem

Nemes Magdolna

Debreceni Egyetem

Hajdú Péter (2016): Reflexek, tanulás és viselkedés. Betekintés a gyermeki elmébe címü könyv (recenzió). Különleges Bánásmód, II. évf. 2016/4. szám, 111-113. DOI 10.18458/KB.2016.4.111

\section{Solly Goddatd Biythe \\ Reflexek, tanulás és viselkedés}

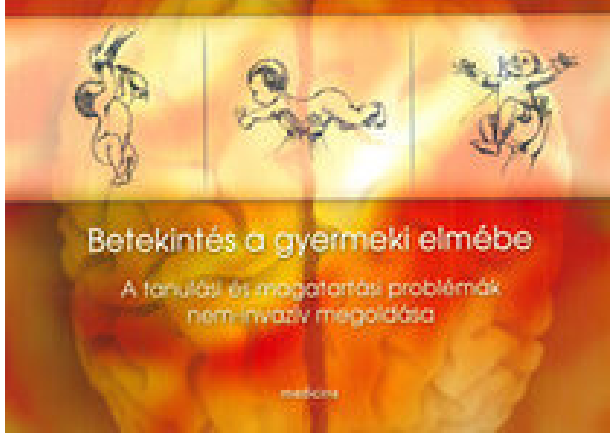

A recenzió alapjául szolgáló mü bibliográfiája:

Sally Goddard Blythe (2015): Reflexek, tanulás és viselkedés. Betekintés a gyermeki elmébe. Medicina Könyvkiadó Zrt., Budapest. 183 oldal ISBN: 9789632265414

Kulcsszavak: tanulási problémák, reflexek, gyógypedagógia

Diszciplinák: pedagógia, pszichológia

\section{Bibliography of the subject of this recension:} Sally Goddard Blythe (2015): Reflexes, learning and behavior - Insights into the child's mind. Medicina Könyvkiadó Zrt., Budapest. 183 oldal ISBN: 9789632265414

Keywords: learning problems, reflexes, special education

Disciplines: pedagogy, psychology

Sally Goddard Blythe a Neurofiziológiai Pszichológiai Intézet igazgatónője iskolák százaiban vezette be a módszerét külföldön, amelyet számos, az emberi idegrendszer fejleszthetőségét bizonyító kutatás is alátámasztott. A Goddard-módszert Magyarországon is oktatják, már az ezredforduló óta. A módszer azon a gondolaton alapul, hogy csak megfelelő 
idegrendszeri fejlettséggel rendelkező gyerekeknél alkalmazhatóak hatásosan a különbözö oktatási módszerek. Az ilyen gyermekeknél alkalmazhatóak hatásosan a különböző oktatási módszerek. Az ilyen gyermek fejlődik, előre halad, ellentétben azzal a gyermekkel, akinél olyan reflexek is érvényesülnek, amelyeket, már régen ki kellett volna nőnie.

Ez a könyv nemcsak arra tanítja meg a szülőket, szakembereket, és érdeklődőket, hogy felismerjék a nehézségek és az elmaradás okát, hanem arra is, miként és milyen gyakorlatokkal segítsék a gyermekeket.

A főbb témakörökről, fejezetekröl:

1. A reflexek és a sikerekre vagy kudarcokra gyakorolt hatásuk az oktatásban. Az újszülött elhagyja az anyaméh nyújtotta biztonságot, és állandó hőmérsékletet, és a külvilágba érkezve olyan mérhetetlen mennyiségü információ zúdul az újszülöttre, hogy ilyenkor még nem tudja feldolgozni, csak a primitív (veleszületett) reflexek tudnak nekik segítséget nyújtani. A primitív reflexek megjelenése változó, van olyan ami az anyaméhben megjelenik és a szültéskor megszünik viszont, van olyan is, ami születés után jelentkezik és legkésőbb 12 hónapos korára el is tünik. A primitív reflexeket külön-külön értékelve megtudhattuk, hogy egy kóros reflex, nem csak fizikai, hanem szellemi visszahanyatlást is mutathat, és ennek következtében a tanulás is nehezítetté válik. A fizikai hanyatlást az esetek döntő többségében a gerincferdülés, és rossz háttartást eredményezett.

2. Primitív reflextöl a testtartás szabályozásáig. Az előző fejezetben megismerhettünk a primitív reflexeket, és azok kialakulását illetve megszűnését. Minden reflex kivétel nélkül fontos szerepet játszik abban, hogy a gyermek a kor előrehaladtával milyen testtartásnak örvend. A helytelen testtartás is vezethet figyelem zavarhoz, ami tanulási nehézségekhez vezethet, és ezáltal az iskolai eredmények vagy leromlanak, vagy sose lesznek olyanok, mint egy átlag gyermeknek, csak korrepetáló tanár segítségével. Ehhez segítséget nyújt ezt a fejezet ugyan is, megnézhettuik milyen a helyes reflex tartás elöre, és hátra, és ha abnormalitást veszünk észre, akkor jelezhetjük gyermekorvosnak, hogy mit tapasztaltunk.

Azok a primitív reflexek amik 9-12 hónapos kornál tovább érzékelhető, akkor abszolút kijelenthető, hogy abnormalitás figyelhetö meg a gyermeknél. Ez az abnormalitás kezelhető és kordában tarható.

3. Az agy fejlödése és az érzékszervek. Az agy, az agytörzs, a kisagy, illetve a féltekék kialakulásáról, és azok különbségéről olvashatunk. Megtudhatjuk, hogy melyik agyrész milyen funkcióért felel, és hogyan tudjuk azt ellenőrizni, hogy már kórosan megtartott az a funkció vagy még az egészséges reflexek közé tartozik. Vannak olyan vizsgálati módszerek, mellyel ezek a kóros reflexek kimutathatóak, és kezelhetőek az agy stimulálásával.

Az érzékszervek között, nem csak a külvilággal kapcsolatok érzékszerveket mutatja be a könyv, hanem a szervezeten belüli érzékeléseket. A látás, a hallás, a szaglás érzékeinek kóros aktivitását, és azok helyreállításának vizsgálati következményeiről leírtak után kiderül, hogy hogyan lehet a gyermek viselkedését, és szellemi képességének a javítani.

4. Reflexek vizsgálata. A kutatásban 15 reflexet ismerhetünk meg részletesebben, aszerint, hogy mikor alakultak ki, meddig mondható egészségesnek, és hogy mikor válik egy reflex kóros folyamatnak, mely a gyermek életkörülményét, és az egészségét hátráltatja. A reflexek vizsgálatát, képekkel, ábrákkal is illusztrálták a jobb megértés érdekében. Megismerhetjük a reflexek közötti különbségeket, és azt is, hogy milyen egy egészséges és egy kóros reflex.

Minden vizsgálatra a gyermekek 0-4 pontos rendszerbe kapnak pontszámot. 0 pontot kap az a személy, akinél nem tapasztalható az adott teszt kapcsán semmiféle rendellenesség. Ezzel ellentétben a 4-es pontérték komoly problémát jelent. 
5. Hogyan segithetünk? A könyv nem akar fejlesztő szakembert képezni az olvasóból, hanem szeretné megmagyarázni, milyen idegrendszeri, neurológiai tényezők játszanak szerepet egy gyermek fejlődésében, és rámutatni a fejlesztésben rejlő lehetőségekre. Minden gyermek fejlődése egyedi, ezért csak egy megfelelően képzett és tapasztalt szakember nyújthat számára megfelelő segítséget.

A reflexvizsgálatokkal meghatározhatjuk a gyermek számára megfelelő fejlesztő programot. A kezelés fajtája nem csak a probléma súlyosságától, hanem a lehetőségektől is függ, vagyis az iskolában rendelkezésre álló fizikai feltételektől, speciális fejlesztő szakemberektől és fejlesztési módszerektől.

A gyermekeket 3 szintbe lehet sorolni az előző fejezet pontértékei alapján. Értelemszerüen minél több pontot ért el a vizsgált egyén annál kidolgozottabb, az ő állapotára specifikus reflexkorrekciós (reflex ingerlési és gátló) programra van szüksége.

A fejezetben szó esik arról is, hogy a szülők milyen módon tudnak segíteni a gyermeküknek. Külön-külön megbeszélésre kerül a különféle szintek javítására szolgáló feladatok és gyakorlatsorok: az I. szinten csak szakember segíthet, a II. szinten besegít a szakember a szülöknek, a III. szinten lévő gyermeknél általános fejlesztő gyakorlatsorozat elég, ahhoz hogy a reflexek normálisak legyenek.

6. Egy gondolat kibontakozása - elmélkedések a reflexekröl. Ebben a fejezetben betekintést nyerünk maga a reflex szó eredetéről, és első kutatási eredményeiről. Híres kutatókat sorolnak fel, akik az 1800-as évektől foglalkoztak a reflexvizsgálatokkal. Az elmúlt 30 évből a klinikai kutatások közül 7 nagyobbat kiemelnek és időrendben értékelnek, illetve az eredményeket bemutatják.

7. Összegzés és esettanulmányok. Ebben a fejezetben 3 érdekes esettanulmányt írt le az írónő, melyek 2 serdülő fiú és egy felnőtt férfiról szólnak (mind a hármójuknak tanulási problémái voltak). A könyv tartalmi részében leírtak alapján elvégeztették velük is a vizsgálatokat, mely alapján kimutatható volt, hogy melyik reflex maradt meg kóros formában. Miután rájöttek melyik reflex volt kórosan visszamaradott, vagy jelenlévő, elkezdték azt kezelni, és a kezelési ciklus előtt és után is elvégeztek egy rajzos kísérletet, mely alapján, fejlödést mutattak a személek.

Összegezve: a könyv kellő alapossággal mutatja be azokat a vizsgálati formákat, illetve tüneteket, melyeket akár egy laikus, akár egy tanár, ha figyelmen kísér, és szakértő segítségével megoldja azokat, akkor sokat javulhatnak egy-egy gyermek tanulási jellemzői. Konkrét gyógyítási példák nincsenek a könyvben, hiszen - ahogyan az írónő is fogalmazott, ha nem szakember segítségével végezzük el a reflexek gyógyítását, akkor nem, hogy segítünk, hanem még árthatunk is a gyermekeknek.

A könyvet olyan szülőknek, vagy tanároknak tudnám javasolni, akik jeleit vélik felfedezni, olyan kóros reflexnek, melyhez már szakember segítsége kell, és nem tudják megoldani magukban. 